\title{
Incidence of Binge Drinking in a Cohort of University Students of the South-East Region of Brazil, 2010-2011
}

\author{
Nathalia Sernizon Guimarães ${ }^{1}$, Aline Silva de Aguiar Nemer ${ }^{2}$, Claúdia Aparecida Marliére \\ de Lima ${ }^{3}$, Juliana Inácio Costa ${ }^{4}$ and Maria Arlene Fausto ${ }^{3, *}$ \\ ${ }^{1}$ Health and Nutrition Programme of the Federal University of Ouro Preto - UFOP, Brazil \\ ${ }^{2}$ Department of Nutrition/ICB of the Federal University of Juiz de Fora - UFJF, Brazil \\ ${ }^{3}$ School of Nutrition of the Federal University of Ouro Preto - UFOP, Brazil \\ ${ }^{4}$ Health Sciences Infectious Diseases Programme of the Federal University of Minas Gerais - UFMG, Brazil
}

\begin{abstract}
Objectives: The aim of the present study was to evaluate the prevalence and incidence of binge and at-risk alcohol consumption among new-entrant students in a public university in the South-East Region of Brazil.

Methods: Longitudinal study undertaken with a random sample of undergraduates $(N=1,168)$ in the first semesters of $2010(n=256)$ and $2011(n=183)$. In order to evaluate drinking patterns, participants were classified as abstainers, light, moderate, binge or heavy binge drinkers. The Alcohol Use Disorders Identification Test (AUDIT) questionnaire score was used to define the risk categories for consumption: low risk, risk, harmful use and probable dependence. Statistical analysis was undertaken using Stata software, version 11.0.

Results: Amongst the 256 students evaluated, $51.6 \%$ were women and $64.5 \%$ were aged $\geq 19$ years. The prevalence of consumption of alcoholic beverages was $75.8 \%$. The average age of onset of alcohol consumption was $15.7 \pm 1.9$ years. The incidence of binge + heavy drinkers was 2.6/100 persons per year, with vulnerability shown in individuals of male sex and of age 19 years or more. The incidence of risk level drinkers was 2.0/100 persons per year and greater for individuals of male sex and younger than 19 years.
\end{abstract}

Conclusion: The students of this institution are at high risk for problems associated with alcohol use.

Keywords: Alcoholic Beverages, Longitudinal Data, Prevalence, Incidence, University Students.

\section{INTRODUCTION}

Alcohol is a psychoactive substance whose use is legal commercially and acceptable socially [1]. The consumption of alcohol is associated with a variety of acute and chronic consequences, be they individual or collective, which range from lesions due to traffic accidents to chronic diseases such as cancer and cardiovascular disease [2].

In Brazil, the consumption of alcohol and other drugs is more frequent in the university population compared to the general population [3]. For a significant portion of students, the national data suggest that the onset of exposure to alcohol is prior to entry to higher education [3]. In the latest National Survey that investigated the consumption of psychotropic drugs amongst students in primary and secondary education, $60.5 \%$ of students reported having already used alcohol at some point in life and, of these, $63 \%$ declared having started to consume alcoholic beverages before age 15 [4].

*Address correspondence to this author at the Universidade Federal de Ouro Preto - Escola de Nutrição - Campus Universitário - Morro do Cruzeiro, s/nOuro Preto - MG - Zip: 35.400-000, Brazil; Tel: +55 0313559 1820; Fax: +55 0313559 1828; E-mail: mariaarlenefausto@gmail.com
In Brazil, there are few studies that investigate the consumption of alcohol amongst recent-entry students in higher education institutions [5,6]. In light of the national scenario of alcohol consumption in primary and secondary education, it is important to identify and monitor the pattern of consumption of alcoholic beverages amongst students of higher education institutions so that actions to prevent and intervene in the abusive consumption of alcohol can be planned adequately.

The objective of the present study was to evaluate the prevalence and incidence of binge and at-risk use of alcohol by recent-entry students in a public university of the South-East Region of Brazil.

\section{METHODS}

This longitudinal study had an average duration of 1 year and was undertaken in 2 campuses of a federal university of the South-East Region of Brazil. This study was approved by the Ethics in Research with Human Beings committee of UFOP (CAAE 0003.0.238.000-09). Participants in the study were all the selected students who agreed to, and signed, a free and informed term of consent. 
The population of this study was composed of 1,168 recent-entry students in the undergraduate courses of this university. A prevalence of alcohol use of $73.5 \%$ [7], variance of $5 \%$, and confidence level of $95 \%$ were used for the sample size calculation, resulting in a minimum sample of 239 students. The selection of the simple random sample was made using the official list of students that enrolled at the institution in March 2010.

After the selection of the sample, the educational institution made the list of subjects and lesson timetables of each selected student available, allowing their location during the data collection stage.

Volunteers previously trained in the application of questionnaires undertook the collection of data. In the first data collection, undertaken in the March to July 2010 period, 256 students participated and in the follow-up stage, March to July 2011, 183 students participated. Reasons for loss to follow-up (28.5\%) were refusal to continue in the study, absenteeism, temporary suspension of education, academic mobility and absence on health grounds. In order to evaluate trends in losses to follow-up, the variables of gender and age range were compared for those students who remained in the study and those lost to follow-up and no differences were observed. Of the 183 students that continued in the study, only 177 answered all of the AUDIT questions.

During the interview, information about gender, birth date, and whether the individual consumed alcohol was obtained. Those who declared consumption of alcoholic beverages were asked to inform the age at which they first drank, whom they were with on the occasion of their first exposure to alcohol and to answer the Alcohol Use Disorders Identification Test (AUDIT) questionnaire [8]. The AUDIT questionnaire score was used to define risk categories of alcohol consumption: low risk ( 0 to 7 points), risk (8 to 15 points), harmful consumption (16 to 19 points) and probable alcoholic dependence $(\geq 20$ points) [8]. Information on the length of time (years) of the individual's alcohol consumption was determined as the age at which the individual drank for the first time to their current age. This time was categorized in quartiles $(\leq 25,>25$ to 75 , and $>75)$ for the presentation of results. The age at which the individual first drank was categorized as $<18$ years or $\geq 18$ years, based upon Brazilian legislation. The pattern of alcohol consumption was determined from the responses to AUDIT questions 1 and 2 and was classified as: light drinkers (consumption $\leq 2$ units and frequency $\leq 1$ occasion/month), moderate drinkers (consumption $>2$ and $<5$ units and frequency 1 to 4 occasions/month), binge drinkers (consumption $\geq 5$ units per occasion and frequency $\leq 1$ occasion/month) and heavy binge drinkers (consumption $\geq 5$ units per occasion and frequency $\geq 2$ occasions/month) $[3,8,9]$.

The database was constructed with dual input to Epidata software, version 3.1. The statistical analysis was undertaken with Stata software, version 11.0, adopting a significance level of less than $5 \%$.

Prevalence of alcohol consumption was estimated using information from the first data collection. For incidence calculations, prevalent cases were excluded from analysis. The incidence of binge drinkers, heavy binge drinkers and total binge drinkers (consumption $\geq 5$ units per occasion) was calculated. The follow-up period was defined as the time between the start date of the study and the date of the last data collection or loss. Individuals with only one evaluation were censored on the second visit, adding to the average expected time between the two stages of the study (0.25 years).

In order to compare the basic information according to gender and age range, the Chi-Squared test was used. In order to compare any alteration in patterns of consumption of alcoholic beverages between students who participated in the two stages of the study and who answered the AUDIT questionnaire, Cochran's $Q$ test was used.

\section{RESULTS}

Of the 256 students who participated in the foundation stage of the study, $51.6 \% \quad(n=132)$ were women and $64.5 \%$ were aged $\geq 19$ years. Amongst the students who declared consumption ( $n=194), 86.6 \%$ initiated the consumption of alcoholic beverages with friends, $85.6 \%$ started to drink under the age of 18 and $73.2 \%$ had consumed alcoholic beverages for more than 2.6 years (Table $\mathbf{1}$ ). The median time of consumption of alcoholic beverages was 4.1 years (P25-P75: 2.6- 6.2 years). The average age of initial consumption of alcohol was $15.7 \pm 1.9$ years, with no significant difference observed between genders $(p=0.39)$. No significant difference was found when comparing information on whom first drinks were taken with, age at onset of drinking, and time of consumption of alcohol by gender. Consumption was more frequent in individuals of male gender $(81.4 \%$ vs $70.4 \%)$ and older individuals ( $81.3 \%$ vs $72.7 \%)$. 
The prevalence of consumption of alcoholic beverages was $75.8 \%$. The prevalences of binge consumption, heavy binge drinking and at-risk consumption were $30.7 \%, 17.2 \%$ and $41.4 \%$, respectively.

The incidences of binge drinkers, heavy binge drinkers and of the association binge + heavy binge drinkers were $1.0 / 100$ persons per year, $1.6 / 100$ persons per year and 2.6/100 persons per year (Table
2). The incidences of heavy binge drinkers and of the association binge + heavy binge drinkers were higher amongst individuals of male sex and of the age range younger than 19 years. Binge drinkers, in turn, show the same incidence rates for both genders and age ranges.

Table 3 shows the incidence rates of drinkers of atrisk alcohol consumption, harmful use, and probable alcohol dependence, based on the total score of the

Table 1: Basic Information about the Consumption of Alcoholic Beverages of Recent-Entry University Students of a Public Institution in the South-East Region of Brazil, 2010

\section{Information about Alcohol Consumption}

Do you consume alcoholic beverages? $(n=256)$

Yes
No

With whom did you drink the first time? $(n=194)$

\begin{tabular}{|c|c|c|}
\hline Family & 23 & 11.8 \\
\hline Friends & 168 & 86.6 \\
\hline Did not answer & 3 & 1.6 \\
\hline
\end{tabular}

At what age did you start to drink? $(n=194)$

\begin{tabular}{|c|c|c|}
\hline$<18$ & 166 & 85.6 \\
\hline$\geq 18$ & 25 & 12.9 \\
\hline Did not answer & 3 & 1.5 \\
\hline
\end{tabular}

Time of consumption of alcoholic beverages $(n=194)$

\begin{tabular}{|c|c|c|}
\hline$\leq 2.6$ years & 49 & 25.3 \\
\hline$>2.6-6.2$ years & 93 & 47.9 \\
\hline$>6.2$ years & 49 & 25.3 \\
\hline Did not answer & 3 & 1.5 \\
\hline
\end{tabular}

Pattern of alcohol consumption $(n=256)$

\begin{tabular}{|c|c|c|}
\hline Abstainers & 4 & 1.5 \\
\hline Light drinkers & 51 & 19.9 \\
\hline Moderate drinkers & 14 & 3.5 \\
\hline Binge drinkers & 78 & 17.2 \\
\hline Heavy drinkers & 44 & 1.2 \\
\hline Did not answer & 3 & 24.2 \\
\hline Non-drinkers & 62 & \\
\hline AUDIT Questionnaire $(\mathrm{n}=256)$ & \multicolumn{3}{|c|}{23.8} \\
\hline Low risk & 61 & 41.4 \\
\hline Risk & 106 & 5.9 \\
\hline Harmful & 15 & 3.1 \\
\hline Probable dependence & 8 & 24.2 \\
\hline Non-drinkers & 62 & 1.6 \\
\hline
\end{tabular}


Table 2: Incidence of a Pattern of Binge and Heavy Binge Consumption of Alcoholic Beverages Amongst University Students in a Public Institution in the South-East Region of Brazil

\begin{tabular}{|c|c|c|c|c|}
\hline Alcohol ingestion pattern & Person-time & Events & $\begin{array}{c}\text { Rate (100 } \\
\text { persons/year) }\end{array}$ & Cl $95 \%$ \\
\hline \multicolumn{5}{|l|}{ Binge + Heavy Drinkers } \\
\hline Total & 1604.10 & 41 & 2.55 & $1.88 ; 3.47$ \\
\hline \multicolumn{5}{|l|}{ Gender } \\
\hline Male & 732.49 & 21 & 2.86 & $1.87 ; 4.39$ \\
\hline Female & 871.61 & 20 & 2.29 & $1.48 ; 3.55$ \\
\hline \multicolumn{5}{|l|}{ Age range } \\
\hline$<19$ years & 101.0 & 4 & 3.96 & $1.48 ; 10.55$ \\
\hline$\geq 19$ years & 1503.1 & 37 & 2.46 & $1.78 ; 3.40$ \\
\hline \multicolumn{5}{|l|}{ Binge Drinkers } \\
\hline Total & 1846.36 & 30 & 1.62 & $1.14 ; 2.32$ \\
\hline \multicolumn{5}{|l|}{ Gender } \\
\hline Male & 828.13 & 13 & 1.57 & $0.91 ; 2.70$ \\
\hline Female & 1018.23 & 17 & 1.67 & $0.10 ; 2.68$ \\
\hline \multicolumn{5}{|l|}{ Age range } \\
\hline$<19$ years & 136.72 & 2 & 1.46 & $0.03 ; 5.85$ \\
\hline$\geq 19$ years & 1706.64 & 8 & 1.63 & $1.13 ; 2.37$ \\
\hline \multicolumn{5}{|l|}{ Heavy Drinkers } \\
\hline Total & 2010.23 & 17 & 0.84 & $0.05 ; 1.36$ \\
\hline \multicolumn{5}{|l|}{ Gender } \\
\hline Male & 1014.43 & 11 & 1.08 & $0.60 ; 1.96$ \\
\hline Female & 995.80 & 6 & 0.60 & $0.27 ; 1.34$ \\
\hline \multicolumn{5}{|l|}{ Age range } \\
\hline$<19$ years & 101.02 & 2 & 1.98 & $0.49 ; 7.90$ \\
\hline$\geq 19$ years & 1909.21 & 15 & 0.78 & $0.47 ; 1.30$ \\
\hline
\end{tabular}

Cl: Confidence Interval 95\%.

AUDIT questionnaire. The incidence rates of these events were $2.0 / 100$ persons per year, $0.3 / 100$ persons per year and $0.2 / 100$ persons per year, respectively. Men and individuals younger than 19 years presented the highest incidence rates for at-risk consumption. For harmful alcohol consumption, women and individuals of 19 years or more presented the highest incidence rates. On evaluating the consumption in probable dependence, the same rates of incidence were observed in both genders and rates were higher in individuals of 19 years or more.

Table 4 shows the classification of student drinkers by gender, according to AUDIT questionnaire score. Amongst the students who declared they drank, the largest percentage of students was encountered in the at-risk category in both stages of the study. The change in classification was significant only for individuals of male sex $(p=0.04)$.

\section{DISCUSSION}

The average age of onset of use of alcoholic beverages observed in this study (15.7 years) is similar to that encountered in the National Survey I on the Use of Alcohol, Tobacco and Other Drugs Amongst University Students (15.3 years), and in studies undertaken with Brazilian students in secondary education $[1,3,10,11]$. The early age of experimentation with this substance and the time interval over which these individuals consume alcoholic beverages (73.2\% had consumed alcohol for more than 2.6 years) indicate that the alcoholic habit precedes university entry. This information is corroborated by other studies which suggest that the earlier the use of such a substance, the greater the harm to the individual in the future $[12,13,14]$.

Among the various factors that may be related to the early age of onset and habit of consuming alcohol, 
Table 3: Incidence of Alcohol Drinkers of at-Risk Consumption, Harmful Use and Probable Dependence Amongst University Students of a Public Institution of the South-East Region of Brazil

\begin{tabular}{|c|c|c|c|c|}
\hline AUDIT Classification & Person-time & Events & Rate (100 persons/year) & Cl $95 \%$ \\
\hline \multicolumn{5}{|l|}{ Risk } \\
\hline \multicolumn{5}{|l|}{ Gender } \\
\hline Male & 801.67 & 17 & 2.12 & $1.31 ; 3.41$ \\
\hline \multicolumn{5}{|l|}{ Age range } \\
\hline$<19$ years & 124.85 & 4 & 3.20 & $1.20 ; 8.54$ \\
\hline$\geq 19$ years & 1562.81 & 29 & 1.85 & $1.29 ; 2.67$ \\
\hline \multicolumn{5}{|l|}{ Harmful } \\
\hline Female & 1120.03 & 4 & 0.35 & $0.13 ; 0.95$ \\
\hline \multicolumn{5}{|l|}{ Age range } \\
\hline$<19$ years & 126.16 & 0 & 0 & 0 \\
\hline$\geq 19$ years & 2053.93 & 7 & 0.34 & $0.16 ; 0.71$ \\
\hline \multicolumn{5}{|l|}{ Probable Dependence } \\
\hline Total & 2213.08 & 4 & 0.18 & $0.07 ; 0.48$ \\
\hline \multicolumn{5}{|l|}{ Gender } \\
\hline Male & 1070.65 & 2 & 0.19 & $0.05 ; 0.75$ \\
\hline
\end{tabular}

Cl: Confidence Interval 95\%.

Table 4: Alterations in the AUDIT Classification of University Students of a Public Institution of the South-East Region of Brazil, 2010/2011, by Gender ( $N=177)$

\begin{tabular}{|c|c|c|c|c|c|c|c|c|c|c|c|c|c|c|c|}
\hline \multirow{3}{*}{$\begin{array}{c}\text { AUDIT } \\
\text { Classification }\end{array}$} & \multirow{2}{*}{\multicolumn{2}{|c|}{$\begin{array}{l}\text { Start of } \\
\text { study }\end{array}$}} & \multirow{2}{*}{\multicolumn{2}{|c|}{ End of study }} & \multirow{3}{*}{$p^{*}$} & \multicolumn{4}{|c|}{ Men } & \multirow{3}{*}{$p^{*}$} & \multicolumn{4}{|c|}{ Women } & \multirow{3}{*}{$p^{*}$} \\
\hline & & & & & & \multicolumn{2}{|c|}{ Start } & \multicolumn{2}{|c|}{ End } & & \multicolumn{2}{|c|}{ Start } & \multicolumn{2}{|c|}{ End } & \\
\hline & $\mathbf{n}$ & $\%$ & $\mathbf{n}$ & $\%$ & & $\mathbf{n}$ & $\%$ & $\mathbf{n}$ & $\%$ & & $\mathbf{n}$ & $\%$ & $\mathbf{n}$ & $\%$ & \\
\hline Low risk & 36 & 20.34 & 48 & 27.12 & \multirow[t]{5}{*}{0.168} & 17 & 17.17 & 30 & 30.3 & \multirow[t]{5}{*}{0.037} & 19 & 24.36 & 18 & 23.08 & \multirow[t]{5}{*}{0.841} \\
\hline Risk & 83 & 46.89 & 69 & 38.98 & & 50 & 50.51 & 35 & 35.35 & & 33 & 42.31 & 34 & 43.59 & \\
\hline Harmful & 10 & 5.65 & 16 & 9.04 & & 7 & 7.07 & 10 & 10.1 & & 3 & 3.85 & 6 & 7.69 & \\
\hline Dependence & 6 & 3.39 & 6 & 3.39 & & 4 & 4.04 & 2 & 2.02 & & 2 & 2.56 & 4 & 5.13 & \\
\hline Non-drinkers & 42 & 23.73 & 38 & 21.47 & & 21 & 21.21 & 22 & 22.22 & & 21 & 26.92 & 16 & 20.51 & \\
\hline
\end{tabular}

${ }^{*}$ Cochran's $Q$

is the absence of surveillance and penalization for infractions of Law n. 8069/90, in which the prohibition of sale of alcohol to those younger than 18 years is stated [15]. 
The prevalence of consumption of alcoholic beverages amongst students in this study was rather high and similar to that found by Nunes et al. who observed a prevalence of consumption of $71.5 \%$ among university students in the health field [16]. On the other hand, a transverse study conducted at the same institution which evaluated a sample of students properly matriculated in the second semester of 2007 found a lower prevalence of alcohol consumption in relation to that observed in this study [17].

The high incidence of university binge drinkers + heavy binge drinkers found in this study suggests that a significant portion of students at this university may present an augmented risk for problems related to the excessive consumption of alcohol such as academic and negative organic consequences cited in the study by Aguiar-Nemer et al. [17].

The higher incidence of heavy binge drinkers of male sex may be explained by socio-cultural and biological factors such as the greater exposure/access of these individuals to festive environments, and this suggests a greater vulnerability of men to risk-taking behaviours $[18,19]$.

Concordant with the international study undertaken by Vergara, 2008, a higher incidence of at-risk use of alcohol was observed in this cohort [20]. According to the applied tool $(A U D I T)$, this fact suggests that although these individuals do not exhibit current problems, they may, in the future, present health problems and suffer/cause injury, violence, legal or social problems and/or produce low performance in their studies due to acute intoxication episodes. This scenario may be reversed by proposing the establishment of abstinence targets or the compliance of drinking patterns with limits considered low risk $[8,21]$.

The main limitation of this study is recall bias, a common fact when it is necessary that the subject remember the frequency and quantity of consumption of beverages, which hinders understanding of their usual consumption, although resources were used so that this consumption might be recalled, as indicated by Willet, 1998 [22].

It is worth highlighting that the comparison between the incidence and alterations in the pattern of alcohol consumption of the university students of this study with other students is difficult due to the scarcity of longitudinal epidemiological studies.

\section{CONCLUSION}

The results of this study indicate that the recententry students of this university are at high risk for problems associated with the use of alcohol and it is necessary to develop preventive programmes for this target population specifically.

\section{FUNDING}

Fundação de Amparo à Pesquisa do Estado de Minas Gerais (APQ-00217-09), Coordenacão de Aperfeiçoamento de Pessoal de Nível Superior (CAPES) and Universidade Federal de Ouro Preto.

\section{REFERENCES}

[1] Reis A, Barros J, Fonseca C, et al. Prevalência da ingestão de álcool nos adolescentes: Estudo Pinga. Rev Port Clin Geral 2011; 27: 338-46.

[2] Rehm J. The risks associated with alcohol use and alcoholism. Alcohol Res Health 2011; 34: 135-43.

[3] Andrade AG, Duarte PCAV, Oliveira LG. I Levantamento Nacional sobre o Uso de Álcool, Tabaco e Outras Drogas entre Universitários das 27 Capitais Brasileiras. Brasília, 2010.

[4] Carlini ELA, Noto AR, Sanchez ZM, et al. IV Levantamento Nacional Sobre o Consumo de Drogas Psicotrópicas Entre Estudantes do Ensino Fundamental e Médio das Redes Pública e Privada de Ensino de 27 Capitais Brasileiras. Brasília 2010.

[5] Ramis TR, Mielke GI, Habeyche EC, et al. Tabagismo e consumo de álcool em estudantes universitários: prevalência e fatores associados. Rev Bras Epidemiol 2012; 15: 376-85. http://dx.doi.org/10.1590/S1415-790X2012000200015

[6] Picolotto E, Libardoni LFC, Migott AMB, Geib LTC Prevalência e fatores associados com o consumo de substâncias psicoativas por acadêmicos de enfermagem da Universidade de Passo Fundo. Ciênc Saúde Coletiva 2010; 15: $645-54$ http://dx.doi.org/10.1590/S1413-81232010000300006

[7] Vieira VCR, Priore SE, Ribeiro SMR, Franceschini SCC Almeida LP. Perfil socioeconômico, nutricional e de saúde de adolescentes recém-ingressos em uma universidade pública brasileira. Rev Nutr 2002; 15: 273-82. http://dx.doi.org/10.1590/S1415-52732002000300003

[8] World Health Organization (WHO). AUDIT: The alcohol use disorders identification test. Guidelines for use in primary health care. Geneva, WHO, Switzerland 1992.

[9] Silveira CM, Silveira CC, Da Silva JG, Silveira LM, Andrade AG, Andrade LHSG. Epidemiologia do beber pesado e beber pesado episódico no Brasil: uma revisão sistemática da literatura. Rev Psiq Clin 2008; 35: 31-9. http://dx.doi.org/10.1590/S0101-60832008000700008

[10] Nardi FL, Cunha SM, Bizarro L, Dell'Aglio DD. Drug use and antisocial behavior among adolescents attending public school in Brazil. Trends Psychiatry Psychother 2012; 34: 802.

\section{http://dx.doi.org/10.1590/S2237-60892012000200006}

[11] Campos JADB, Almeida JC, Garcia PPNS, Faria JB. Consumo de álcool entre estudantes do ensino médio do município de Passos - MG. Ciênc Saúde Coletiva 2011; 16: 4745-54.

http://dx.doi.org/10.1590/S1413-81232011001300023 
[12] Vieira DL, Ribeiro M, Laranjeira R. Evidence of association between early alcohol use and risk of later problems. Rev Bras Psiquiatr 2007; 29: 222-7. http://dx.doi.org/10.1590/S1516-44462007000300006

[13] Jackson KM, Sher KJ, Cooper ML, Madeira PK. Álcool e tabaco uso do adolescente: início, persistência e trajetórias de uso em duas amostras. Addict 2002; 97: 517-31. http://dx.doi.org/10.1046/j.1360-0443.2002.00082.x

[14] Casswell S, Pledger M, Pratap S. Trajetórias de beber de 18 e 26 anos: identificação e previsão. Addict 2002; 97: 142737.

http://dx.doi.org/10.1046/j.1360-0443.2002.00220.x

[15] Brasil. Código civil: lei n. ${ }^{\circ} 8.069$ de 13/07/1990. Dispõe sobre - Estatuto da Criança e do Adolescente e dá outras providências. 102 ed. Brasília: 1990.

[16] Nunes JM, Campolin ${ }^{a}$ LR, Vieir ${ }^{a}$ MA, Caldeir ${ }^{a}$ AP. Consumo de bebidas alcoólicas e prática do binge drinking entre acadêmicos da área da saúde. Rev Psiq Clín 2012; 39: 94-9. http://dx.doi.org/10.1590/S0101-60832012000300005

[17] Aguiar-Nemer AS, Fausto MA, Silva-Fonseca VA, Ciomei $\mathrm{MH}$, Quintaes KD. Pattern of alcoholic beverage consumption and academic performance among college students. Rev Psiq Clín 2013; 40: 65-70.

http://dx.doi.org/10.1590/S0101-60832013000200003

[18] Morgana Scheffer M, Almeida RMM. Consumo de álcool e diferenças entre homens e mulheres: comportamento impulsivo, aspectos cognitivos e neuroquímicos. Revista Neuropsicologia Latinoamericana 2010; 2: 1-11.

[19] World Health Organization (WHO). WHO Expert Committee on problems related to alcohol consumption. Geneva, WHO, Switzerland: 2007.

[20] Vergara KMA. Consumo patológico de alcohol entre lós estudiantes de la universidad de Cartagena, 2008. Rev Salud Pública 2009; 11: 878-86. http://dx.doi.org/10.1590/S0124-00642009000600004

[21] World Health Organization (WHO) Global status report: alcohol and young people. Geneva, WHO, Switzerland: 2001.

[22] Willett WC. Nutritional Epidemiology. $2^{\text {th }}$ ed. New York: Oxford University Press, 1998. http://dx.doi.org/10.1093/acprof:oso/9780195122978.001.000 1

(C) 2013 Guimarães et al.; Licensee Lifescience Global.

This is an open access article licensed under the terms of the Creative Commons Attribution Non-Commercial License (http://creativecommons.org/licenses/by-nc/3.0/) which permits unrestricted, non-commercial use, distribution and reproduction in any medium, provided the work is properly cited. 